\title{
Beer giant blindsides Ventria's pharmacrop
}

Ventria Bioscience, a Sacramento, Californiabased biotech company scuttled plans in May for growing two of its genetically modified (GM) rice varieties in southern Missouri this year after being blindsided by beer maker Anheuser-Busch. Ventria officials describe the decision as a minor setback that will not deter them from growing GM rice there next year. Even so, the Missouri-centered spat provides a reminder of how biotech companies developing plant-made pharmaceutical (PMP) products, despite strict compliance with regulations, may be subject to unpredictable, last-minute upheavals that can waylay seasonally sensitive plans and jeopardize business activity. Still, forecasted high market demand means the long-term prospects of such crops may not be compromised.

"We'd had discussions with AnheuserBusch, but were not aware of concerns," recalls Scott Deeter, Ventria president and CEO, referring to the St. Louis-based brewing giant. The company had been lured from California to Missouri with the offer of substantial incentives and the involvement of several state officials, including the governor, state-level legislators, both senators and several representatives, and also leaders at Northwest Missouri State University (NMSU) in Maryville. In particular, NMSU President Dean Hubbard invited Ventria, which he has called the "perfect fit," to become part of a "Center of Excellence for plant-made pharmaceutical production" on that campus. In May, state legislators also agreed to provide an initial \$1 million in funding for the NMSU center, with much more promised in the future both for the center and in incentives for the company.

Yet, with the agbiotech company in the final stages of planning a field trial of a rice strain engineered to produce human lysozyme and another to produce human lactoferrin, Anheuser-Busch sent shockwaves when it suddenly threatened to boycott all rice from Missouri if the state allowed Ventria's planting of GM rice to go ahead. Apparently, the brewer was concerned that the GM rice would outcross and 'contaminate' other rice grown in the state used as feedstock in the company's beer manufacturing process.

In the run up to the dispute, Ventria had dutifully obtained key permits from the US Department of Agriculture that are needed before planting about 200 acres with two GM rice varieties in the state's southern ricegrowing region. Containment plans included extended buffer zones, use of self-pollinating seeds that would not be subject to wind- or

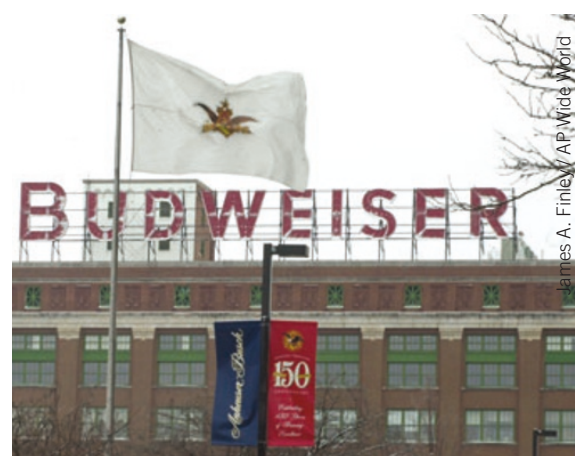

Anheuser-Busch, whose flag flies in front of the Budweiser brewery in St. Louis opposed Ventria's plans to cultivate transgenic pharmacrops

insect pollination and provisions for monitoring and managing the growth, harvesting and processing of those crops.

With the boycott looming, top state officials scrambled into action, bringing Ventria and Anheuser-Busch back to the negotiating table in April. A deal was then clinched in which Ventria agreed to plant its rice in the north, more than 120 miles away from the prized rice-growing regions in the state. Meanwhile, the brewing company agreed to purchase locally produced rice.

The dispute was seized upon by several other groups concerned about the potential for admixture between Ventria's rice and conventional rice used for foods and beverages. These included rice growers in Missouri and Arkansas (e.g., Riceland Foods), food industry representatives (e.g., the Grocery Manufacturers of America and the Food Products Association, both in Washington, DC) as well as environmental groups.

Citing past "adulteration of the food supply by Starlink corn," for example, the Food Products Association is insisting on "mandatory regulatory oversight to prevent contamination" of foods by PMPs (Nat. Biotechnol. 19, 11, 2001). Bill Freese of Friends of the Earth in Washington, DC, calls PMPs an "idea whose time is past" and claims that they "will almost certainly contaminate conventional crops... and simply aren't working." He also points to incidents in 2002 in Iowa in which conventional corn became contaminated with PMP corn being grown by College Station, Texas-based ProdiGene (Nat. Biotechnol. 21, 3-4, 2003).

What's happened is "a setback to Ventria... and certainly not a good thing and unfortunate," says Andrew Baum, president and CEO of SemBioSys Genetics in Calgary, Alberta in
Canada, which has not encountered opposition when testing its GM safflower. He sees those troubles arising inevitably when outside forces, in this case food producers, maneuver to override the science-based regulatory system that governs the PMP sector of the biotech industry. Some see the need to step away from food crops to ensure the future of the sector. "So far, knock on wood and quite to the contrary of [food] crops, tobacco is being embraced by the food industry as a preferred platform for PMPs," says Dave Duncan, president and CEO of Chlorogen in St. Louis. His company very deliberately is using tobacco rather than a food/feed crop so as to avoid both the possibility and the "perception" that its GM plants could impinge on global food markets, he points out.

Lisa Dry of the US Biotechnology Industry Organization (BIO) in Washington, DC, believes the outlook for PMPs is positive. "The market and demand for new drugs is so great and the capacity issues so critical that PMPs are going to happen," she predicts. According to a report by consultancy Frost \& Sullivan released in December 2004, the US market for PMPs could be worth $\$ 2.20$ billion by 2011 . Some think the first products could reach the market around 2005/2006.

With this in mind, BIO has developed, and soon will release information to prepare the ground for companies and help all parties involved face challenges like those encountered by Ventria in Missouri. The BIO handbook "Containment Analysis and Critical Control Point Plan" is designed to provide a road map and plan for those involved in PMP plantings.

At present, Ventria plans to grow only nontransgenic varieties in northern Missouri this year to "adapt" its breeding stocks to local conditions. But it also is pursuing plans to grow GM rice varieties in "multiple locations in North Carolina," pending additional federal permits. Furthermore, when suitable sites are identified and permits obtained, the company hopes to carry out more plantings "in the Southern hemisphere, so we can have two growth cycles per year," he says.

In the near term, Ventria plans to market purified, PMP lactoferrin as a safer, nonanimal ingredient for boosting production of medicinals in cell-culture systems and for research uses. The company is also consulting with Food and Drug Administration officials about lactoferrin's potential use in "medical foods," which might be used to combat illnesses such as severe childhood diarrhea, Deeter notes.

Jeffrey L. Fox, Washington, DC 